\title{
chę
}

\section{Monitoramento eletrônico como medida de proteção às mulheres vítimas de violência}

\section{Lia Gondim Araujo}

Mestra em Planejamento e Políticas Públicas - UECE

\section{Maria Helena de Paula Frota}

Doutora em Sociologia pela Universidade de Salamanca

Professora do Programa de Pós-Graduação em Políticas Públicas (PPGPP) da

UECE

\section{Resumo}

Este artigo tem por objetivo abordar os conceitos e as experiências do monitoramento eletrônico de homens agressores como medida de proteção às mulheres vítimas de violência. Adotando a pesquisa documental e bibliográfica como metodologia, constatou-se que o fato da medida ter sido implantada recentemente no Brasil (há 4 anos) demanda avanços tanto em termos de formalizar a aplicação dessa medida como de avaliar as ações que afetem diretamente os atores sociais em questão. No primeiro momento, aborda-se o tema em caráter geral e, seguida, analisam-se dados sobre a violência contra a mulher, bem como conceitos e aspectos relativos à origem do monitoramento eletrônico.

Palavras-chave política pública penal; prisão; violência contra a mulher; monitoramento eletrônico.

\begin{abstract}
This article aims to address the concepts and experiences of electronic monitoring of male aggressors as a measure to protect female victims of violence. Adopting documentary and bibliographic research as a methodology, it was found that the fact this measure was recently deployed in Brazil (4 years ago) requires advances both in terms of formalizing the application of this measure and evaluating actions that directly affect the social actors concerned. At the first moment, the theme is addressed in a general way, then data on violence against women are analyzed, as well as concepts and aspects related to the origin of electronic monitoring.
\end{abstract}

Key words criminal public policy; prison; violence against women; electronic monitoring.

Conhecer: debate entre o público e o privado

2018, Vol. 08, nㅇ 20

ISSN 2238-0426

DOI: 10.32335/2238-0426.2018.8.20.1053

Licença Creative Commons Atribuição 


\section{Introdução}

O Brasil é um país formado, em sua maioria, por mulheres. Ao longo dos anos, elas vêm conquistando reconhecimento e espaço na família, na sociedade, no trabalho, dentre outras esferas. Analisando os dados da população brasileira por sexo, disponibilizados pelo Instituto Brasileiro de Geografia e Estatística ([IBGE], 2010), verificou-se que, em 2015, a composição por sexo foi de $51,6 \%$ de mulheres, ou seja, 105,5 milhões de brasileiras, e $48,4 \%$ de homens, o equivalente a 99,4 milhões de brasileiros.

No que concerne ao Nordeste, a população de mulheres alcança $51,5 \%$ do total. A razão de sexo atinge um índice alto nessa região, com 95,3 homens para cada 100 mulheres, enquanto a média da razão de sexo no Brasil é de 96. No Rio de Janeiro, por exemplo, a razão de sexo é baixa: 88 homens para cada 100 mulheres.

Em contrapartida, o Nordeste é a 2 ${ }^{\text {a }}$ região com maior taxa de homicídios de mulheres, registrando 5,6 mulheres assassinadas a cada 100 mil mulheres em 2013. A primeira posição nesse quesito coube à Região Norte: 6,1 mulheres assassinadas a cada 100 mil mulheres.

Pode-se observar que essas taxas decorrem de circunstâncias locais e não globais. As regiões Norte e Nordeste concentram as maiores taxas de homicídios de mulheres e, desde o período colonial, são ocupadas por homens conservadores, corajosos e machistas, o que justifica a chamada "nordestinação" da violência contra as mulheres.

No Ceará, o Censo Demográfico de 2015 contabilizou uma população de 8,4 milhões de pessoas, das quais 4,3 milhões são mulheres (51\%).

O estudo de Waiselfisz (2015) sobre a violência contra a mulher, que constitui o foco deste estudo, indica que o Ceará ocupa a 8a posição em homicídios femininos, com uma taxa de 6,2 homicídios a cada 100 mil mulheres. Ou seja, um número mais elevado do que a maior média por região: 6,1.

Dentre as capitais brasileiras, Fortaleza ocupa a 4a posição em número de homicídios de mulheres, com taxa de 10,4 homicídios femininos a cada 100 mil mulheres. Isso equivale a quase o dobro acima da média das capitais, que é de 5,5 mulheres assassinadas a cada 100 mil mulheres. Tanto na região Nordeste como no Ceará, as taxas de homicídios se encontram acima da média do país, o que confirma a relevância desta pesquisa. Há um número elevado de homens e mulheres na região, em comparação a outras, o que tende a favorecer os atos de violência. Entretanto, ao analisar os possíveis fatores propiciadores dos homicídios, nota-se que são complexos e que consistem, no mínimo, em três: a) relações de dominação masculina; b) patriarcalismo; e c) relacionamento em si.

De acordo com o Sistema de Informação sobre Mortalidade (SIM), no período entre 1980 e 2013 foram assassinadas, no Brasil, mais de 106 mil mulheres, sendo 43,5 mil na última década. O número de vítimas de assassinato aumentou $252 \%$, passando de 1.353 mulheres em 1980 para 4.762 em 2013. 
Diante desses dados, vale destacar a efetivação de uma política pública penal voltada à prevenção de tal violência e à proteção das mulheres. A partir da Lei n. 11.340/2006 (Lei Maria da Penha - LMP), tem-se adotado medidas de prevenção à violência contra as mulheres, segundo as quais o agressor pode ser afastado do convívio da vítima por meio das chamadas medidas protetivas de urgência.

Este artigo atribui ênfase a essa função do equipamento jurídico, tendo em vista que, desde 2014, o Estado brasileiro vem aplicando a técnica com o intuito de impedir o contato físico entre a vítima e o agressor, até que o processo seja julgado. Elabora-se, ainda, um breve histórico sobre a política pública penal brasileira, no que concerne às condições do sistema prisional e do sistema judiciário, salientando as penas alternativas à prisão, com ênfase ao dispositivo aplicado em cumprimento à LMP.

Tendo em vista o curto tempo de aplicação do monitoramento eletrônico no Ceará, cerca de 4 anos, para fins de fiscalização imediata e efetiva das medidas protetivas de urgência, constante na LMP, e a ausência da sua regulamentação legal, almejamos, também, aprofundar o interesse no tema e estimular a reflexão sobre a violência contra a mulher e a questão de gênero, uma vez que demandam atenção por parte do Estado.

Este artigo se divide em 3 seções, além desta introdução e das considerações finais. Na primeira se abordam as categorias política pública penal e prisão. A segunda versa sobre a violência contra mulher, a partir das diferentes correntes históricas que a definem, além de suas estatísticas no Brasil, no Nordeste, no Ceará e na Grande Fortaleza. E a terceira se debruça sobre o objeto de estudo, o monitoramento eletrônico. Inicialmente, o texto apresenta os conceitos pertinentes e aspectos técnicos internacionais, nacionais e locais. Assim, pode-se compreender o uso do monitoramento eletrônico no Brasil e como ele passou a ser adotado no Ceará, bem como sua ascensão enquanto medida protetiva das mulheres.

\section{Políticas públicas e sistema penal: breves considerações}

De início, pergunta-se: como definir política pública se não há uma definição única? Souza (2006) discrimina as principais definições, como a de Mead (1995), que a conceitua como um campo que analisa o governo de acordo com as questões públicas; já Lynn (1980) aponta ações do governo com efeitos específicos, ao passo que Peters (1986) fala na soma das atividades dos governos, que agem diretamente ou por meio de delegação, que influenciam a vida dos cidadãos. Entretanto, segundo a autora, a definição mais conhecida pertence a Harold Laswell, que sintetiza seu conceito respondendo aos seguintes questionamentos: Quem ganha o quê? Por quê? e Que diferença faz? 
Celina Souza (2006) resume política pública como um campo em que se busca colocar o governo em ação, analisar tal ação e, se necessário, estabelecer novos rumos para as ações subsequentes.

A política pública é formulada a partir do programa de governo, no sistema democrático, em que são discriminados os propósitos e as ações para atingir os objetivos e os resultados. Segundo Souza (2014), cada política pública perpassa um ciclo de atividades que se inicia na formação da agenda de governo, a partir de uma demanda de interesse público, como, por exemplo, a violência contra a mulher, que demanda uma política pública baseada na luta dos movimentos sociais em defesa das mulheres e em dados estatísticos registrados em sistemas de informação do Estado. Dependendo do governo, a política é elaborada junto com os interessados, por meio de conferências realizadas com movimentos sociais, e, no caso do objeto deste estudo, com movimentos organizados de mulheres. A política pública envolve vários atores e níveis de decisões.

Segundo Filocre (2009), para elaborar a política de segurança pública, o Estado deve interligar um modelo que interaja com as políticas existentes, tais como saúde e educação, não somente em relação aos dados sobre criminalidade, mas a toda a realidade que a envolve. Por exemplo, de acordo com o autor, deve-se considerar o local onde ocorre o crime, as ocorrências localizadas e o perfil do acusado (idade, gênero, raça, cor, renda etc.). Porque uma área com alto índice de criminalidade também pode não possuir uma política pública de educação ou possuí-la, porém, com avaliação negativa, bem como ser uma área vulnerável a doenças por falta de assistência na área da saúde, ou mesmo por falta de oportunidade de emprego e renda. O formulador da política é quem deve ser capaz de perceber essas situações.

Para Araujo (2014), o sistema prisional brasileiro não vem comportando o trabalho de tanta repressão, devido às atuais políticas aplicadas no campo da segurança pública serem reativas e limitarem-se a gerenciar crises, com respostas imediatas a problemas pontuais.

A política criminal de repressão adotada no país não tem correspondido à realidade de conflitos estabelecida na vida urbana. "Uma política pública de segurança deve ter a capacidade de articular a repressão e prevenção ao crime, tem que trabalhar com a participação e envolvimento dos demais atores da sociedade" (Araujo, 2014).

Nos últimos 14 anos, a população de presos aumentou 167,32\%, ficando muito acima do crescimento populacional. É a quarta maior população carcerária do mundo, sendo que o Brasil é o quinto mais populoso do planeta, ficando atrás dos Estados Unidos da América (EUA), que possui mais de 2,2 milhões presos, China (1,6 milhões) e Rússia (644 mil). Considerando países com uma população de 10 milhões de pessoas ou mais, o Brasil tem a sexta maior taxa de presos, com 306 a cada 100 mil habitantes, mais do que o dobro da taxa mundial de encarceramento, que é de 144 presos a cada 100 mil habitantes (Brasil, 2014). 
Há três regimes para o cumprimento dessas penas: regime fechado; regime semiaberto; e regime aberto. No fechado, o infrator cumpre sua pena em presídio de segurança máxima. No semiaberto, o apenado pode trabalhar durante o dia e recolher-se à noite. No aberto, o condenado passa o dia livre e retorna à noite para alojamento.

Em conformidade com o Código de Processo Penal (CPP), a prisão pode ser processual e para cumprimento de pena. São diversos os tipos de prisão processual, tais como: em flagrante; preventiva; temporária; domiciliar; para extradição; do devedor de alimentos; e do depositário infiel.

Tendo por base dados do sistema prisional, de 31 de dezembro de 2014, verificou-se que a população carcerária brasileira consiste em mais de 622 mil presos (Tabela 1).

Tabela 1 - Pessoas privadas de liberdade no Brasil em dezembro de 2014

\begin{tabular}{|l|c|}
\hline População prisional & $\mathbf{6 2 2 . 5 9 9}$ \\
\hline Sistema prisional estadual & 584.758 \\
\hline Secretarias de segurança/carceragem de delegacias & 37.444 \\
\hline Sistema penitenciário federal & 397 \\
\hline Vagas & 371.884 \\
\hline Déficit de vagas & 250.318 \\
\hline Taxa de ocupação & $167 \%$ \\
\hline Taxas de aprisionamento & 306,22 \\
\hline
\end{tabular}

Fonte: Elaborada pela autora.

A população total é o somatório das populações prisionais do sistema estadual (584.758 presos), mais as das secretarias de segurança (37.444 presos), e mais a do sistema penitenciário federal (397 presos) totalizando 622.599 presos no Brasil. Segundo dados do InfoPen (Brasil, 2014), 90\% das unidades prisionais são administradas pelo Poder Público. Em 15 estados, as unidades sob gestão pública representam um valor próximo ou igual a 100\%. Apenas nos estados do Amazonas e Bahia há unidades com cogestão. Apenas 6 estados têm unidades geridas por organizações sem fins lucrativos e apenas o Estado de Minas Gerais possui parcerias público-privadas (PPP).

O Brasil apresenta uma das maiores taxas de aprisionamento do mundo, 300 presos a cada 100 mil habitantes, enquanto a taxa mundial é de 144 presos a cada 100 mil habitantes, ou seja, mais do que o dobro da média.

Os países que encontram à frente do Brasil em população carcerária, em sentido contrário ao do nosso país, vêm diminuindo seus índices de prisão. De acordo com o InfoPen, "o ritmo de crescimento do encarceramento entre as mulheres é ainda sensivelmente mais acelerado, da ordem de $10,7 \%$ ao ano, saltando de 12.925 mulheres privadas de liberdade 
em 2005 para a marca de 33.793, registrada em dezembro de 2014" (Brasil, 2014, p. 6).

Como se observa na Tabela 1, há um déficit de mais de 250 mil vagas para presos. Trata-se de um número alarmante: tais condições de insuficiência de vagas motivam diversas rebeliões organizadas pelos próprios presos em busca de melhores condições na prisão. Para Oliveira (2012, p. 14), há outro agravante:

\footnotetext{
O abalo constante dos padrões da Justiça é revelado, por exemplo, na atual realidade penitenciária, tipicamente criminalizante, no contexto de um sistema arcaico propício para a internalização dos apodrecidos valores da vida carcerária, sempre a fomentar, dia a dia, malefícios que, na teoria se propõe a evitar. A prisão é sempre um poço de insegurança de onde os indivíduos saem sem saber exatamente onde vão estar na próxima noite. Enfim, a prisão é o espaço da tortura dos vazios se arrastando no tempo.
}

Esse cenário é corroborado pelo relatório do InfoPen (Brasil, 2014), que indica um sistema prisional crítico, devido à superlotação e às péssimas condições de estrutura física. Outrossim, o Departamento Penitenciário (Depen) (Brasil, 2015a, p. 19) traz outra visão da prisão, considerando-a um espaço de minorias sociais: "[a] prisão é o espaço ocupado por minorias sociais que, antes de 'lotar' o cárcere, já se encontravam privadas de direitos fundamentais como educação, trabalho, saúde, moradia, entre outros".

A Constituição Federal de 1988 (CF/1988) prevê em seu artigo 5º, incisos LXV e LXVI: "LXV - a prisão ilegal será imediatamente relaxada pela autoridade judiciária; e LXVI ninguém será levado à prisão ou nela mantido, quando a lei admitir a liberdade provisória, com ou sem fiança”. Assim, a prisão, é medida extrema que se aplica somente nos casos expressos em lei e quando a hipótese não comportar nenhuma das medidas cautelares alternativas.

Há 7 anos, o sistema prisional tem apresentado mudanças consideráveis em relação ao tipo de pena a ser aplicada em casos de prisão preventiva, por exemplo. O CPP foi inovado pela Lei n. 12.403/ 2011, que determina ao juiz a obrigação de converter em prisão preventiva a prisão em flagrante delito somente quando apurada a impossibilidade de relaxamento ou concessão de liberdade provisória, com ou sem medida cautelar diversa da prisão.

Além de prevenir e evitar a superlotação nos presídios, a iniciativa dessa lei teve como premissa combater e prevenir a prática de tortura no momento da prisão. Com essa lei, o preso em flagrante é conduzido imediatamente à autoridade judicial, atendendo ao direito à integridade física e psicológica das pessoas presas, garantido no artigo 52 da Convenção Americana de Direitos Humanos e no artigo 21 da Convenção Contra a Tortura e Outros Tratamentos ou Penas Cruéis, Desumanos ou Degradantes - o que é um avanço. 
Em meio às agruras enfrentadas pelo sistema prisional, um novo mundo se revela via progresso tecnológico, com a globalização. Sempre estamos sendo "vigiados", muitas vezes por meio de videomonitores, para prevenir atentados contra bens e pessoas, em monitoração de imagens de câmeras instaladas nas ruas, nas estradas, nos estacionamentos, no interior de lojas, de condomínios, nos estádios, nas próprias prisões, ou de outras formas.

Como progresso para reduzir os índices de prisão, o Conselho Nacional de Justiça (CNJ) e o Ministério da Justiça firmaram os Acordos de Cooperação n. 05, 06 e 07, em 9 de abril de 2015, que estabelecem medidas cautelares diversas da prisão, aplicadas no âmbito das audiências de custódia e encaminhadas para acompanhamento em serviços instituídos preferencialmente no âmbito do Poder Executivo estadual, denominados Centrais Integradas de Alternativas Penais ou outra nomenclatura, bem como às Centrais de Monitoramento Eletrônico, em casos estritos (Pimenta, 2016).

O autor destaca, ainda, que o monitoramento deve ser instalado de forma gradativa. (Pimenta, 2016), de acordo com a Resolução n. 213/2015, do CNJ, e não deve constituir elemento adicional de controle para autuados que, pelas circunstâncias apuradas em juízo, já responderiam ao processo em liberdade. Entretanto, a medida deve ser aplicada exclusivamente a pessoas acusadas por crimes dolosos puníveis com pena privativa de liberdade máxima superior a 4 anos ou condenadas por outro crime doloso, em sentença transitada em julgado, ressalvado o disposto no inciso I do caput do artigo 64 do Código Penal (CP), bem como a pessoas em cumprimento de medidas protetivas de urgência acusadas por crime que envolva violência doméstica e familiar contra mulher, criança, adolescente, idoso, enfermo ou pessoa com deficiência, sempre de forma excepcional, quando não couber outra medida cautelar menos gravosa (Pimenta, 2016) .

Diante das diversas formas de aplicação da monitoração, este artigo se restringe ao monitoramento eletrônico de agressores, como medida de proteção às mulheres.

\section{A violência contra a mulher}

A violência contra a mulher vem acontecendo há muitos anos no Brasil. A novidade que se observa há pouco mais de 10 anos e que tem constituído uma grande conquista e encorajamento para as mulheres, bem como uma forma de intimidação dos homens, é a LMP. Sancionada em agosto de 2006, visa a incrementar e destacar o rigor das punições para o crime de violência contra a mulher.

A LMP cria mecanismos para coibir a violência doméstica e familiar contra a mulher, nos termos do artigo 226 da CF/1988, da Convenção sobre a Eliminação de Todas as Formas de Discriminação contra as Mulheres e da Convenção Interamericana para Prevenir, Punir e Erradicar a Violência contra a Mulher. Ela também dispõe sobre a criação dos Juizados 
de Violência Doméstica e Familiar contra a Mulher e altera o CPP, o CP e a Lei de Execução Penal.

No Brasil, o grande desafio consiste em quantificar esses crimes. Atualmente, com a lei em vigência, os números de crimes praticados contra as mulheres vêm sendo computados a partir de dados do SIM, da Secretaria de Vigilância em Saúde (SVS) do Ministério da Saúde.

Este artigo adota como base de dados o mapa da violência (Waiselfisz, 2015) que considera fontes as informações dos sistemas supramencionados.

Em 2003, a média de taxa de homicídios de mulheres no Brasil era de 4,4 mulheres a cada 100 mil, e no Ceará era quase $50 \%$ menor (2,6). O estado com maior número de homicídios nesse período foi o Espírito Santo.

Em 2013, a taxa no Brasil teve um aumento para 4,8 e muitos outros estados ficaram acima dessa média. Considerando que, na década, a população feminina passou de 89,8 milhões para 99,8 milhões, ou seja, aumento de 11\%, percebe-se que a taxa nacional de homicídios cresceu 8,8\%.

O número de homicídios femininos no Brasil, entre 2003 e 2013, passou de 3.937 para 4.762, representando 13 mortes de mulheres por dia. Além do crescimento nacional de homicídios de mulheres, observa-se, ainda, que após 10 anos, em 2013, o Ceará passou a ter uma taxa de homicídios de 6,2 mulheres para cada 100 mil, classificando-se no 8 lugar de maior número de homicídios.

Nesse intervalo de tempo, o Ceará apresenta um exorbitante crescimento de $140 \%$ em homicídios de mulheres, entre 2003 e 2013, passando de uma taxa de 2,6 para 6,2, corroborando a teoria de Albuquerque (2013) sobre o nordestino violento, machista, corajoso e autoritário.

Delimitando ainda mais o campo do estudo, nota-se que, a capital do Ceará, Fortaleza, é classificada em 4ํ lugar em termos de taxa de homicídios de mulheres, portanto, é onde se concentra maior número de mortes de mulheres no estado, o que justifica, inclusive, o fato da pesquisa ser realizada em Fortaleza e sua Região Metropolitana.

\section{A origem do monitoramento eletrônico}

Araujo Neto (2011, p. 1) define o monitoramento como "um método de controle e observação que pode ser aplicado tanto a seres humanos quanto a coisas, visando conhecer a exata localização, percurso e deslocamento do objeto monitorado". O que é corroborado pelo Decreto n. 7.627/2011 e transcrito no relatório do Depen, que classifica a monitoração como um mecanismo de "vigilância telemática posicional, à distância, de pessoas presas sob medida cautelar ou condenadas por sentença transitada em julgado, executada por meios técnicos que permitam indicar a sua localização" (Brasil, 2011). 
A execução da monitoração é realizada por meio do sistema ativo e/ou pelo sistema passivo. A diferença entre os sistemas ativo e passivo é que o primeiro é considerado contínuo e o mais adotado, com uso de bracelete ou tornozeleira eletrônica, também conhecidos como dispositivos de identificação individual. No segundo, o chamado sistema passivo, a monitoração é realizada esporádica e aleatoriamente, por meio de contato telefônico (Japiassú, 2008, p. 25).

O Ceará aplica o modelo em que a monitoração é realizada com uso de equipamento eletrônico, via GPS, que permite estabelecer restrições à locomoção do indivíduo submetido à vigilância, permitindo que se desloque onde possa ser encontrado. E, o mais importante, esse tipo de monitoração pode impedir o acesso do condenado a determinadas pessoas ou lugares.

O sistema exige, além do dispositivo, sob o corpo do preso, receptor e transmissor de dados de localização, que tenham um centro de vigilância e um terminal de controle. A monitoração é realizada por quatro equipamentos técnicos: um emissor transmissor; um receptor transmissor; um centro de vigilância; e um terminal de controle de monitoração (Oliveira, 2012).

Segundo Oliveira (2012), o emissor transmissor é um bracelete-emissor, usado pelo preso com a finalidade de emitir automaticamente sinais de rádio que permitem saber a exata localização da pessoa monitorada. Pode ser utilizado no pulso (pulseira eletrônica) ou no tornozelo (tornozeleira eletrônica). É mais comum no tornozelo, onde fica menos exposto, proporcionando privacidade ao preso, pois fica coberto por calça ou meia.

Após análise do aparelho junto à Central de Monitoramento Eletrônico do Governo do Estado do Ceará, vinculada à Secretaria de Justiça e Cidadania (Sejus), verificou-se que o equipamento é composto por material hermético, antialérgico e impermeável, podendo ser usado durante o banho (exceto em mergulhos)

Quanto à classificação da monitoração, pode ser dupla ou via dispositivo de duas peças, ou seja, casos em que o réu e a vítima utilizam os aparelhos. Nas situações em que há mulheres vítimas de violência, tanto o agressor utiliza a tornozeleira como ela usa outro tipo de equipamento, denominado unidade portátil de rastreamento (UPR), semelhante ao do agressor, com a diferença de que não fica preso à perna nem ao braço, podendo ser conduzido na bolsa ou bolso da roupa pela vítima.

A tornozeleira possui um lacre, que, ao ser rompido, é imediatamente registrado no sistema de monitoração. O lacre é composto de material plástico, apropriado para ser danificado ao ser rompido indevidamente, de modo a não ser reaproveitado e obrigar o monitorado a se dirigir à Central de Monitoramento Eletrônico para recolocar o lacre.

O aparelho funciona por meio de uma bateria elétrica que emite sinais característicos, que avisam quando está descarregada ou se houve uma pane, cuja carga suporta o uso por 8 a 12 horas por dia, dependendo das ocorrências de deslocamento no dia, e sua recarga 
por meio de carregador, conectado ao aparelho do usuário de tornozeleira, sendo que este, obrigatoriamente, deve carregá-lo, estando acordado, por um intervalo de cerca de 3 horas.

A exigência de que a tornozeleira seja conectada ao carregador quando o usuário estiver acordado é vital, a fim de evitar danos ao equipamento quando deitado em sono profundo, bem como impedir o rompimento da recarga, evitando acionar a Central de Monitoramento Eletrônico desnecessariamente, por falta de carga.

Há dois tipos de sinais utilizados pelo equipamento: o GPS e o GPRS. O primeiro deriva da expressão em inglês global positioning system e fornece a posição geográfica via satélite; já o segundo deriva de outra expressão em inglês, general packet radio service, fornecendo a posição via conexão de internet, por meio do chip instalado na parte interna do aparelho. Caso um sinal seja interrompido, devido à localização e/ou posição do aparelho, o outro fornece a localização exata do monitorado.

A empresa que mais fabrica e aluga o equipamento no Brasil é a Spacecomm Monitoramento S/A. O produto é alugado pelo gestor de segurança pública do Governo Do Estado por meio de licitação, desde 2015. No Ceará, o custo mensal de aluguel da unidade do equipamento ativo é de aproximadamente $R \$ 240,00$.

O centro de controle de monitoração fica localizado, geralmente, nos estabelecimentos prisionais - no caso do Ceará, encontra-se na Sejus. Um funcionário fica encarregado de fazer as fichas de cada pessoa monitorada, indicando as horas de controle. O computador recebe as informações do receptor e verifica se batem com os eventos ocorridos com o monitorado e se este não violou nenhuma regra. Caso o monitorado tente danificar o aparelho, por exemplo, um sinal de alarme é emitido para o Terminal de Controle de Monitoramento (Japiassú, 2008).

É para esse terminal, denominado Central de Monitoramento Eletrônico no Ceará, vinculada à Sejus, que são enviados todos os alertas do Centro de Controle de Monitoramento. Uma vez verificada a violação de alguma regra que o monitorado deve seguir, o fato é imediatamente notificado às autoridades competentes.

Quanto ao modelo de gestão de monitoramento eletrônico, cada país vem adotando o seu. No caso do Brasil, somente em 2016 o Ministério da Justiça, em parceria com o CNJ e o Depen, elaborou as diretrizes gerais da política, para contribuir com as normas de cada estado.

A política ainda é bem recente e requer uma boa gestão dos dados coletados para que possa ser implementada, monitorada e avaliada com efetividade, assim como uma estrutura de acompanhamento psicossocial dos monitorados e de suas famílias.

As primeiras experiências de controle de presos em seu domicílio ocorreram em 1979, quando o magistrado norte-americano Jack-Love, do Novo México, idealizou a criação de um equipamento de vigilância dos presos, inspirado em uma história em quadrinhos do Homem-Aranha, na qual o vilão fixa um bracelete eletrônico conectado a um radar no 
braço do herói, permitindo localizá-lo onde quer que ele esteja (Céré, 2006 como citado em Japiassú, 2008, p. 14).

A implementação da tecnologia de monitoração foi verificada em diversos outros países, como Inglaterra, Portugal, Itália, Alemanha, Escócia, Suécia, Suíça, Holanda, França, Austrália, País de Gales, Andorra, Nova Zelândia, Cingapura, Bélgica, Israel, Taiwan e África do Sul e, na América Latina, Argentina, em Buenos Aires (Vidal, 2014).

$\mathrm{Na}$ Espanha, destaca-se o uso de monitoramento eletrônico no âmbito da violência doméstica, nosso objeto de estudo. Cada país, legisla sobre as diversas formas de aplicação da medida na execução das penas.

A Espanha se destaca internacionalmente quanto à defesa e promoção dos direitos da mulher, mediante a Lei n. 1/2004, com o objetivo de:

[...] atuar contra a violencia que, como manifestação da discriminação, a situação da desigualdade e as relações de poder dos homens sobre as mulheres, exerce-se sobre elas por parte de quem é ou tem sido seus cônjuges ou de quem está ou tem estado ligado a elas por relações similares de afetividade, mesmo sem convivência. Tradução nossa.

No Brasil, o monitoramento eletrônico começou a ser discutido em 2007, logo após a sanção da LMP, que prevê a concessão de medida protetiva de urgência às mulheres vítimas de violência.

Em seguida foi regulamentado pela lei que altera a Execução Penal (Lei n. 12.258/2010), como fiscalização no cumprimento das penas, quando o juiz autoriza as saídas temporárias no regime semiaberto e determina prisões domiciliares.

Em 2011 foram publicados mais dois dispositivos legais que normatizam o Monitoramento Eletrônico: primeiro a Lei n. 12.403/2011, que altera o CPP, admitindo-o como medida cautelar diversa da prisão, em seu artigo 319, inciso IX, um esforço para reduzir o alto índice de presos provisórios - $41 \%$ do universo prisional, de acordo com os dados do InfoPen (Brasil, 2014).

Posteriormente, o Decreto n. 7.627, de 24 de novembro de 2011, regulamentou o monitoramento eletrônico definindo-o em seu artigo $2^{\circ}$ como "vigilância telemática posicional à distância de pessoas presas sob medida cautelar ou condenadas por sentença transitada em julgado, executada por meios técnicos que permitam indicar a sua localização", e estabelecendo que o equipamento deve ser utilizado de modo a respeitar a integridade física, moral e social da pessoa monitorada e a preservar o sigilo dos dados e das informações da pessoa monitorada.

Nesta era da tecnologia, com a superlotação dos presídios e após a promulgação das leis, supramencionadas, o uso da ferramenta de monitoramento eletrônico vem se 
expandindo em vários estados brasileiros, conforme estudo realizado pelo Depen (Brasil, 2015a).

Observou-se que 19 estados utilizam o monitoramento eletrônico, sendo que em 17 deles os serviços se encontram funcionando e em 2 estados eles se encontram em fase de testes, "sinalizando o movimento de expansão da política, 7 Unidades da Federação já apresentam projeto visando implementação dos serviços de monitoração. Fora desta perspectiva, apenas o Amapá não implementou e não apresenta projeto nesta direção" (Brasil, 2015a, p. 33).

O primeiro estado a implantar foi São Paulo, em 2010. Em 2011, a política foi implementada em mais quatro estados: Alagoas, Pernambuco, Rio de Janeiro e Rondônia. Em 2012, foram as vezes do Ceará, Acre e Minas Gerais. Em 2013, Piauí e Rio Grande do Sul. Em 2014, a política foi instalada no Amazonas, Espírito Santo, Goiás, Maranhão, Mato Grosso, Pará e Paraná, completando um total de 17 unidades federativas com o serviço penal de monitoração (Brasil, 2015a, p. 33).

Os recursos são oriundos de convênio firmado entre o Depen e as Unidades da Federação. Por exemplo, entre 2013 e 2015 foram investidos cerca de R $\$ 9$ milhões com monitoramento eletrônico. E, em 2015, foi previsto investimento de R $\$ 26$ milhões (Brasil, 2015a, p. 34).

Segundo o Depen (2015), a capacidade das pessoas monitoradas simultaneamente, segundo a previsão contratual de cada Unidade da Federação, totaliza em nível nacional 40.431 pessoas.

Em 2016, a Coordenadoria Geral de Alternativas Penais apresentou as "Diretrizes e Regras sobre Tratamento e Proteção de Dados", no âmbito de Consultoria Nacional Especializada, para formulação de modelo de gestão de monitoramento eletrônico de pessoas.

Nesse documento são estabelecidas algumas regras comuns aos estados, para que se tenha um sistema de monitoração mais seguro. Dentre as diversas normas, temos: segurança da informação, com a responsabilização da pessoa que ilicitamente realize a divulgação não autorizada de dados pessoais do monitoramento eletrônico; proteção para os integrantes da rede de monitoramento eletrônico, ou seja, os monitorados, bem como os envolvidos nos serviços de monitoramento eletrônico; padronização dos termos de tratamento e proteção de dados; especificação de dados que deve conter o cadastro; e autorização judicial prévia para compartilhamento de dados, dentre outras.

Outra importante contribuição desse documento é a autorização do uso para fins de pesquisa dos dados dos monitorados e das mulheres em situação de violência doméstica e seus familiares, amigos, vizinhos ou conhecidos.

Tendo em vista a criação do Juizado Especial de Violência Doméstica e Familiar em todo o Brasil, alguns estados, como o Espírito Santo e o Ceará, vêm adotando a técnica de 
monitoração em homens agressores de mulheres e nas vítimas, como medida protetiva de urgência, em cumprimento à LMP, como uma forma de prevenir o homicídio de mulheres.

Em 2015 havia 18.172 pessoas monitoradas no Brasil; 88\% eram homens e 12\% eram mulheres, padrão semelhante ao observado na execução penal propriamente dita. Há centrais de monitoramento eletrônico implantadas em 19 unidades da Federação, sendo que em 17 delas os serviços se encontram implementados e em 2 eles estão em fase de teste. O diagnóstico aponta a expansão da política via convênios entre o Depen e as unidades da Federação (Brasil, 2015b).

Vale destacar que, em 2015, apenas 4,21\% dos casos de aplicação de monitoramento eletrônico no Brasil visavam a cumprir medida protetiva de urgência, prevista na LMP, ou seja, a política ainda é timidamente estendida aos crimes de violência contra a mulher.

Em 2014, a fim de aumentar a efetividade da fiscalização e do cumprimento das medidas protetivas de urgência, solicitou-se ao Governo do Estado do Ceará que disponibilizasse tornozeleiras eletrônicas à Justiça.

No Ceará, o monitoramento eletrônico fica sob a responsabilidade da Central de Monitoramento Eletrônico, pertencente à Sejus. À medida que é proferida uma decisão judicial para implementação de tornozeleira eletrônica, o(a) apenado(a) é orientado(a) a comparecer à Central de Monitoramento Eletrônico. Segundo dados da central, obtidos em visita realizada em julho de 2017, o estado tem 1.500 tornozelados(as), sendo que, destes, 20 monitorados(as) ativos(as) cumprem a medida protetiva de urgência prevista na LMP. Em 2014, foram cumpridas 22 decisões judiciais, em 2015 foram 19, em 2016 foram 27 e até junho de 2017 foram outras, 8 decisões judiciais.

A Central de Monitoramento Eletrônico da Sejus constitui uma célula subordinada diretamente ao Gabinete do Secretário; porém, a partir de 2017 ainda não consta na Estrutura Organizacional da Secretaria, como dispõe o Decreto n. 30.983/2012. Anteriormente, era um setor vinculado à Coordenadoria de Inteligência (Coint), também sem constar no regulamento.

Uma considerável parte da infraestrutura da célula e dos núcleos é garantida no contrato pela empresa contratada: sala climatizada com computador, com mecanismo de segurança para acesso restrito a pessoas autorizadas; um número telefônico 0800 , disponibilizado em 5 terminais simultaneamente, que permite ao sentenciado entrar em contato com a central; estações de trabalho, proporcional à quantidade de monitorados(as) ativos(as), do tipo call center, com móveis, computador e acessórios; monitores LED de 50 polegadas; e notebook, tablet, rede interna de dados, mesas, cadeiras, armários, máquina fotográfica, filmadora etc.

O último contrato celebrado, entre o Estado do Ceará, por meio da Sejus, e a empresa Spacecomm Monitoramento S/A teve como objeto a contratação do fornecimento de 3 mil unidades de tornozeleiras eletrônicas, 400 equipamentos para prevenção de violência 
doméstica e todos os insumos necessários para a execução dos serviços. Esses números evidenciam que $13 \%$ das tornozeleiras são reservadas para agressores.

\section{Considerações finais}

Segundo a Sejus, a monitoração proporciona menor custo ao Estado, pois o custo de um preso em unidade prisional é $80 \%$ maior do que o aluguel da tornozeleira (em média, $\mathrm{R} \$ 1.800,00$ mensais por presidiário).

No Ceará, um fato interessante é que o monitoramento eletrônico foi implementado, inicialmente, em Fortaleza e sua Região Metropolitana, sob a prerrogativa da efetivação do controle ser, preferencialmente, efetivado por meio de parceria e apoio da Coordenadoria Integrada de Operações de Segurança (Ciops).

A estrutura da Ciops proporciona atendimento às ocorrências de sinistro, rompimento, tentativa de fuga ou falta de comunicação com o(a) monitorado(a) com rapidez, tornando a monitoração minimamente exequível. Infelizmente, nos municípios onde a CIOPS não tem condições de atender às demandas, não é viável conferir as ocorrências dos(as) monitorados(as), por falta de viatura e pessoal para tal.

Caso ocorra alguma violação, como bateria descarregada, rompimento do lacre, falha no sinal e/ou na identificação da localização do monitorado, ou mesmo a reincidência do crime, o(a) apenado(a) é imediatamente notificado(a) por telefone para comparecer à central. Caso não compareça em até 5 dias, a central elabora um relatório para o juiz, informando detalhes do ocorrido e o fato de que o(a) apenado(a) não se apresentou à Sejus. Em caso de novo crime, o(a) apenado(a) deve ser capturado(a); já o não comparecimento envolve a emissão de mandado de busca por parte do juiz.

Uma equipe de técnicos trabalha 24 horas por dia diante de monitores que indicam os sinais vermelhos de violação pelo nome de monitorado, então, automaticamente, o sistema dispara sinais sonoros, vibratórios e visuais a cada 5 minutos, além de luzes para os equipamentos, indicando bateria descarregada, falha no sinal, saída da área autorizada, entrada na área desautorizada etc.

No caso de aproximação do agressor à vítima, esta recebe, de imediato, uma mensagem em seu celular, enviada automaticamente pelo sistema; além disso, recebe sinais sonoros, vibratórios e visuais a cada 5 minutos, bem como ligação para seu celular com informações sobre a localização do(a) tornozelado(a).

Quando o(a) monitorado(a) não responde aos alarmes e não resolve a pendência, então, o técnico faz a ligação para solicitar que carregue o equipamento, saia da área com sinal fraco, retorne para a área autorizada etc. E nas situações em que as tentativas de ligação não são bem-sucedidas, a Sejus elabora relatório de violação e envia ao juiz para as 
devidas providências de segurança voltadas à vítima. Ressalta-se que as ocorrências mais graves ficam nas primeiras linhas, em destaque.

Em caso de queda de energia ou ausência de técnico para acompanhamento da monitoração na Sejus, a empresa proprietária do sistema, localizada em Curitiba-PR, comunica à contratante, via telefone, os monitorados com ocorrências mais graves. A diferença é que a empresa não visualiza o nome, apenas o código da tornozeleira, em respeito ao sigilo dos dados. Para tal, a Spacecomm Monitoramento S/A é obrigada a proporcionar um sistema capaz de garantir que não haja falta de energia ou oscilação em seu fornecimento, por meio de sistemas tipo no-break, geradores ou alimentação por mais de uma subestação.

Outra medida de segurança obrigatória é a proteção digital de toda a comunicação de dados estabelecida entre o servidor e o cliente do monitoramento eletrônico, por meio de criptografia e certificado digital.

Ademais, toda comunicação estabelecida com os agressores e as vítimas, por meio da Central de Monitoramento Eletrônico e, ainda, da Célula de Monitoramento com a Polícia, deve ser gravada digitalmente e arquivada por tempo indeterminado, para eventuais consultas.

As informações dos monitorados e do sistema são mantidas em sigilo e só são repassadas para outro órgão em casos de rompimento do lacre, fuga do(a) apenado(a) ou decisão judicial. Toda a base de dados, como comunicações gravadas (de voz e texto), é de propriedade do Governo do Estado do Ceará, por meio da Sejus. Para garantir a segurança digital, tais informações são armazenadas em formato criptografado e protegido por senha.

\section{Referências bibliográficas}

Albuquerque, D. M., Júnior. (2013). Nordestino: uma invenção do "falo" - uma história do gênero masculino (1920-1940). São Paulo: Intermeios.

Araújo, T. T. Política de segurança pública na sociedade brasileira sob a ótica das políticas públicas: análise da prevenção criminal e prevenção social. 2014. Disponível em: <temistoclestelmo.jusbrasil. com.br>. Acesso em: 5 nov. 2016.

Araújo Neto, F.; Medeiros, R. R. N. O monitoramento Eletrônico de presos e a Lei no 12.403/2011. Âmbito Jurídico, Rio Grande, v. 23, n. 90, jul. 2011. Disponível em: <http://www.ambito-juridico.com. br/site/index.php?n_link=revista_artigos_leitura\&artigo_id=9894>. Acesso em: 10 out. 2016.

Brasil. (2011). Política Nacional de Enfrentamento à Violência contra as Mulheres. Brasília, DF: Secretaria Especial de Políticas para Mulheres.

Brasil. (2014, dezembro). Levantamento Nacional de Informações Penitenciárias (InfoPen). Brasília, DF: Departamento Penitenciário. 
Brasil. (2015a). Fórum Brasileiro de Segurança. Recuperado de http://www. forumseguranca.org.br/ estatistica/dados-criminais

Brasil. (2015b). A implementação da política de monitoração eletrônica de pessoas no Brasil. Brasília, DF: Ministério da Justiça.

Filocre, D’A. (2009). Classificações de políticas de segurança pública. Revista Brasileira de Segurança Pública, 3(5), 146-157.

Instituto Brasileiro de Geografia e Estatística. (2010). Censo Demográfico 2010. Recuperado de http://www.ibge.gov.br/home/estatistica/

Japiassú, C. E. A. (2008). Monitoramento eletrônico: uma alternativa à prisão? Experiências internacionais e perspectivas no Brasil. Brasília, DF: Conselho Nacional de Política Criminal e Penitenciária.

Oliveira, E. (2012). Direito penal do futuro. São Paulo: Lex.

Pimenta, I. L. (2016). Diretrizes para tratamento e proteção de dados na monitoração eletrônica de pessoas. Brasília, DF: Departamento Penitenciário Nacional.

Souza, C. Políticas Públicas: uma revisão literária. In: Sociologias, Porto Alegre, n. 16, jul./dez 2006. ano 8.

Vidal, Eduarda de Lima. Monitoramento eletrônico: aspectos teóricos e práticos. 2014. 105 f. Dissertação (Mestrado em Direito) - Universidade Federal da Bahia, Salvador, 2014.

Waiselfisz, J. J. (2015). Mapa da violência 2015: homicídios de mulheres no Brasil. Brasília, DF: : Faculdade Latino-Americana de Ciências Sociais. 